\title{
Facies Analysis, Sedimentary Environment and Sequence Stratigraphy of the Carboniferous Deposits of Gachal Formation, Eastern Central Iran (Rahdar Section)
}

\author{
Mohammad Javad Javdan', Mohammad Nabi Gorgij², Javad Shahraki ${ }^{3}$, \\ Seyed Mahmood Pahlavan Hashemi ${ }^{3}$, Seyed Mohsen Kalvandi ${ }^{3}$, \\ Seyed Mohammad Kalvandi ${ }^{3}$, Eshagh Bandani ${ }^{3}$ \\ ${ }^{1}$ Department of Geology, Ferdowsi University, Mashhad, Iran \\ ${ }^{2}$ Department of Geology, Siatan and Baluchestan University, Zahedan, Iran \\ ${ }^{3}$ Department of Geology, Zahedan Branch, Islamic Azad University, Zahedan, Iran \\ Email: *Javad_sh1536@yahoo.com
}

Received 18 July 2015; accepted 22 September 2015; published 25 September 2015

Copyright (C) 2015 by authors and Scientific Research Publishing Inc.

This work is licensed under the Creative Commons Attribution International License (CC BY). http://creativecommons.org/licenses/by/4.0/

(c) (i) Open Access

\section{Abstract}

Early carboniferous deposits of the Kalmard block, with various characteristics in different outcrops, are recognized by Gachal Formation. Generally speaking, this formation comprises of four different members (A, B, C and D), consisting of carbonate and evaporative rocks. Gachal Formation is composed chiefly of 55 meters sandstone and limestone interbedded with shale. According to the lithological and microscopic studies, Gachal Formation is deposited in beach, semi-restricted and open lagoon, shoal and open marine environments. Vertical changes of microfacies and the curve of its depth changes account for the high thickness of the facies of shoal and bar sub-environments and the low thickness of the facies of lagoon and open marine sub-environment as well. Gachal Formation rocks in Rahdar section are deposited in a low-angle homoclinal ramp located in southern Paleothysis Ocean. The carbonate-sandstone sequence in Gachal Formation in Rahdar section is composed of a depositional sequence separated from each other by type 1 sequence boundaries. Deposits of this formation are separated from lower deposits by type 2 sequence boundary and from Khan Group by unconformity. The sedimentary sequence identified in this formation points to the age of late Visean, conforming to Kaskaskia IV. The erosional boundary between Gachal and Khan Formations is relatively compatible with drop in sea level at Late Kaskaskia global scale.

*Corresponding author.

How to cite this paper: Javdan, M.J., Gorgij, M.N., Shahraki, J., Hashemi, S.M.P., Kalvandi, S.M., Kalvandi, S.M. and Bandani, E. (2015) Facies Analysis, Sedimentary Environment and Sequence Stratigraphy of the Carboniferous Deposits of Gachal Formation, Eastern Central Iran (Rahdar Section). Open Journal of Geology, 5, 623-636.

http://dx.doi.org/10.4236/ojg.2015.59055 


\section{Keywords}

Kalmard, Lower Carboniferous, Gachal Formation, Rahdar Section, Homoclinal, Paleothysis, Kaskaskia, Khan Group

\section{Introduction}

Central Iran, shaped like a triangle and as one of the major, largest and most complex geological units in Iran, is located in the center of Iran [1]. The carboniferous carbonate rocks of this block are distinct from others due to having an evaporative member (the member $\mathrm{C}$ of Gachal Formation). The mentioned section is located in the southwestern Tabas (at 1:250,000 scale) and east western Robatkhan (at 1:100,000 scale) in Kalmard Block (eastern central Iran) [2]. This section is framed by the geographical coordinates of $33^{\circ} 16^{\prime} 05^{\prime \prime} \mathrm{N}$ and $56^{\circ} 09^{\prime} 28^{\prime \prime} \mathrm{E}$. Rahdar section is located about 65 kilometers from Tabas-Yazd main road, accessible by a two-kilometer-dirt road (Figure 1).

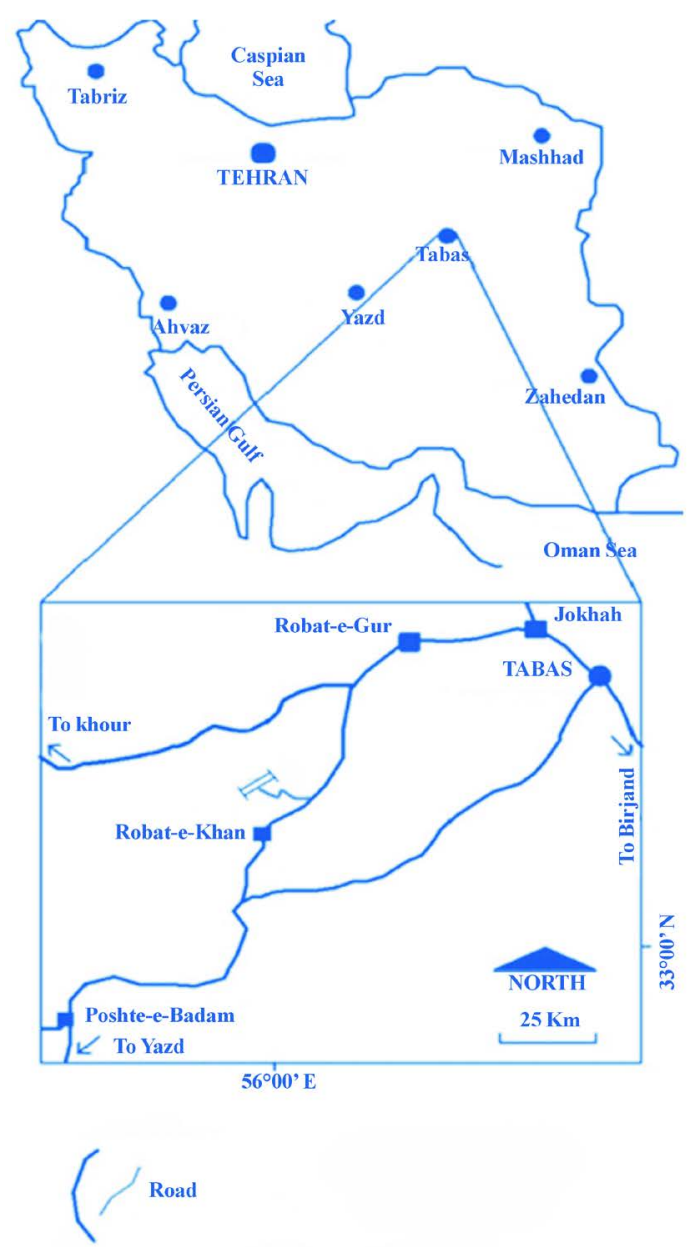

Town, village 


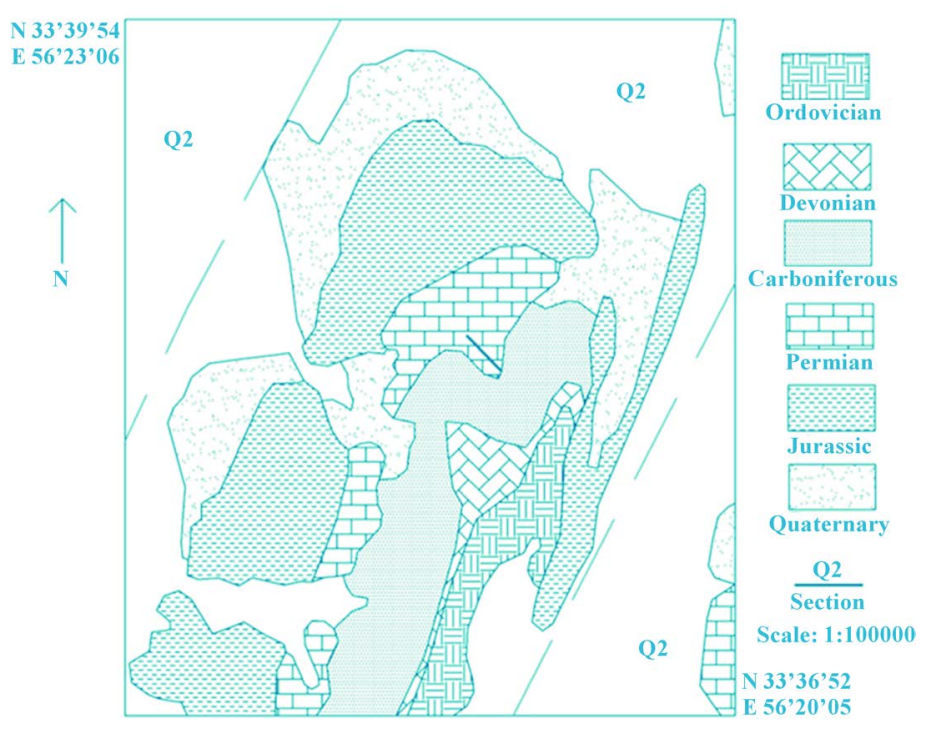

(b)

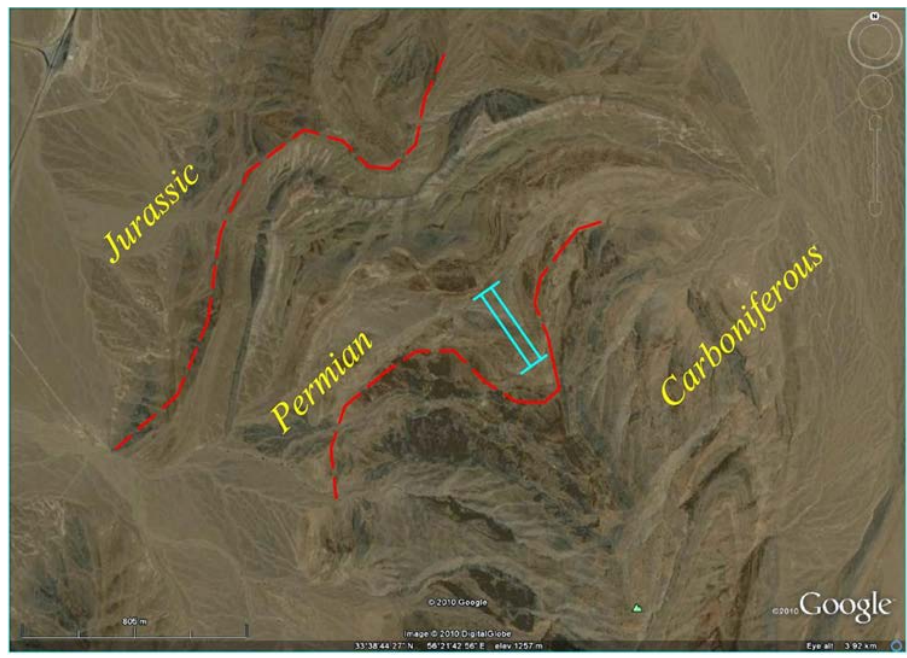

(c)

Figure 1. (a) Geographical position and access ways, (b) geological map of Gachal Formation in Rahdar section, satellite images (c).

\section{Materials and Methods}

The method of this study includes laboratory and field studies. After reviewing aerial maps of the studied zone and several field visits, 1 stratigraphic sections were chosen and studied. From outcrops of Gachal Formation in study area 34 thin sections were provided. In order to find Petrographic features of the studied sections, microscope with PPL and XPL light were applied. With regard to carbonate samples after determining type and percentage of allochem and orthochem elements, the samples were studied with the purpose of proceeding nomenclature and exact identification of sedimentary environment. Dunham's (1962) classification is also used to study and nominate the carbonate rocks, in which the maximum size of matrix grains is 0.06 .

Eventually, parasequences stacking pattern, unconformity surface, system tract and stratigraphic status of the sequence in the global sequences are also determined.

This study aims to achieve the following goals:

- Studying and analyzing the microfacies of Gachal Formation in Rahdar section.

- Restoring the sedimentary conditions of the Kalmard block in early carboniferous based on data gathered from microfacies and field observations. 
- Employing Exxon model to determine the sequences, sequence boundaries and stacking pattern of parasequences depicting sea-level fluctuation curve and its relationship with sea-level fluctuation curve at global scale and in carboniferous era.

In the field studies, the superficial characteristics of the sequence namely thickness, sedimentary structure, type of fossils, etc. as well as number, type and thickness of parasequences are recorded and eventually, samples are collected. Moreover, the key types of sequence stratigraphic surfaces including maximum flooding surface (mfs), sequence boundary (SB), transgressive surface (TS) and marine flooding surface are recognized. Also, this sequence is divided into certain rock units (PR1, PR2 \& PR3).

PR1: involves thin-layered brown sandstones.

PR2: contains medium-to-thick bedded limestones with interbedded gray shales.

PR3: thick-to-massive bedded brown sandstones.

Having studied the sequence and recorded the data, this study determined the sequence stratigraphy and various types of cycles such as Shallowing, Deepening, Retrogradational, Progradational, Aggradational, Brining, Coarsening, Fining, etc. The samples are collected from the sites where the most facies and cyclic changes are found and regarding the repetition of the sedimentary cycles, 34 samples were gathered.

\section{Discussion}

Gachal Formation in the studied section consists of the following four facies belts, facing sea from the coast: Beach (A), Lagoon (B), Shoals and Bar (C) and Open marine (D).

\subsection{Beach Sub-Environment (Facies A) Consists of the Following Microfacies}

\subsubsection{A1: Quartzarenite, Horizentally Laminated Sandstone (Sh)}

Presence of 95\% Quartz with sorting and semi-circular grains in $0.4 \mathrm{~mm}$ size is of these microfacies features, that this microfacies belongs to thin to thick bedded sandstones in light brown color in Gachal Formation. Pressure curve which is of processes during sedimentation and after it, is also seen in these microfacies (Figure 2(b), Figure 2(a1)).

\subsubsection{A2: Quartzarenite, Planar Cross-Bedded Sandstone (sp)}

Presence of 90\% Quartz with weak sorting and semi-circular grains in $0.6 \mathrm{~mm}$ size is of this microfacies features, that this microfacies belongs to thick bedded sandstones in brown color in Gachal Formation Pressure curve which is of processes during sedimentation and after it, is also seen in these microfacies. This facies contains flat diagonal classification and enjoys high frequency in the upper parts of this section. Diagonal layers have an angle between 15 to 20 degrees, accounting for deposits in aqueous environments with unidirectional and bidirectional flows [3] (Figure 2(b), Figure 2(b1)).

\subsubsection{Interpretation}

Beach related facies, indicate relatively high energy conditions in this sub environment. Sandstone facies (Sh). In some places of stone context also iron oxide veins are seen, which are a sign of low-depth and near-surface conditions. This facies consists of horizontally laminated fine-grained sandstones. Regarding the grain size and the relationship between horizontal lamination and high-energy flows in fine-grain sandstones, one can attribute the formation of this facies to the high speed of water flow. Parting lineations are formed at the surface of very fine to fine grain sandstone beds [4]-[10]. Sandstone facies (sp), formed at low speed of water flow and due to the movement of ripples and two-dimensional megaripples [5] [6] [10].

\subsection{Open to Semi-Restricted Lagoon Sub-Environment (Facies B) Consists of the Following Microfacies}

\subsubsection{B1: Bioclastic Algal Pelloid Pelecypoda Packstone}

This facies consists of Dasycladacea algae (10\%) with $3 \mathrm{~mm}$ in size, Pelecypoda (20\%) with 2 mm in size, Pelloid (15\%) with $0.5 \mathrm{~mm}$ in size and well-sorting and well roundness, and skeletal fragments (5\%) with 1 to 2 $\mathrm{mm}$ in size. This facies can be found in the form of medium-to-thick bedded limestones with interbedded gray shales (Figure 3(a)). 


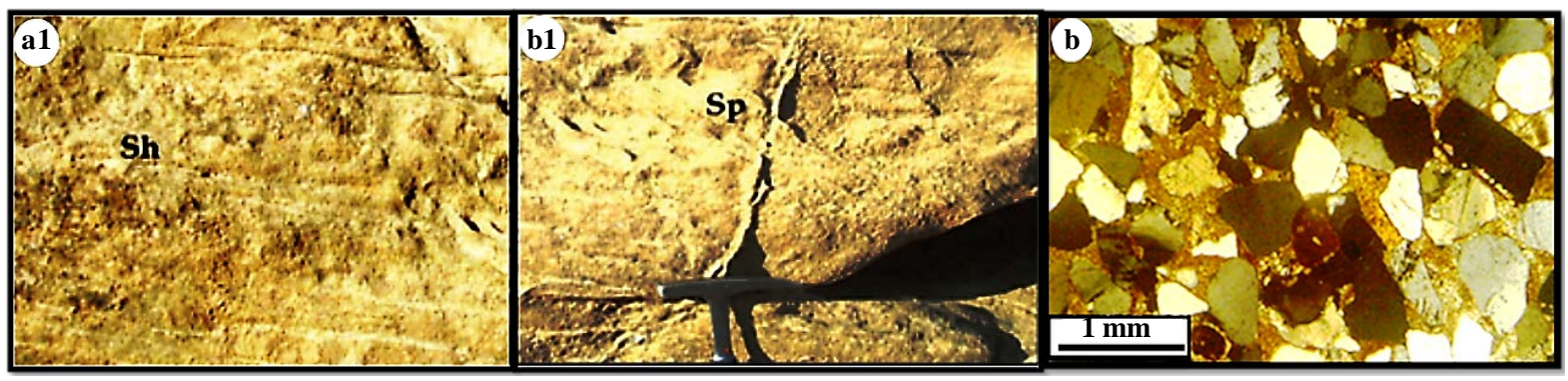

Figure 2. Microfacies of beach environment: quartzarenite.
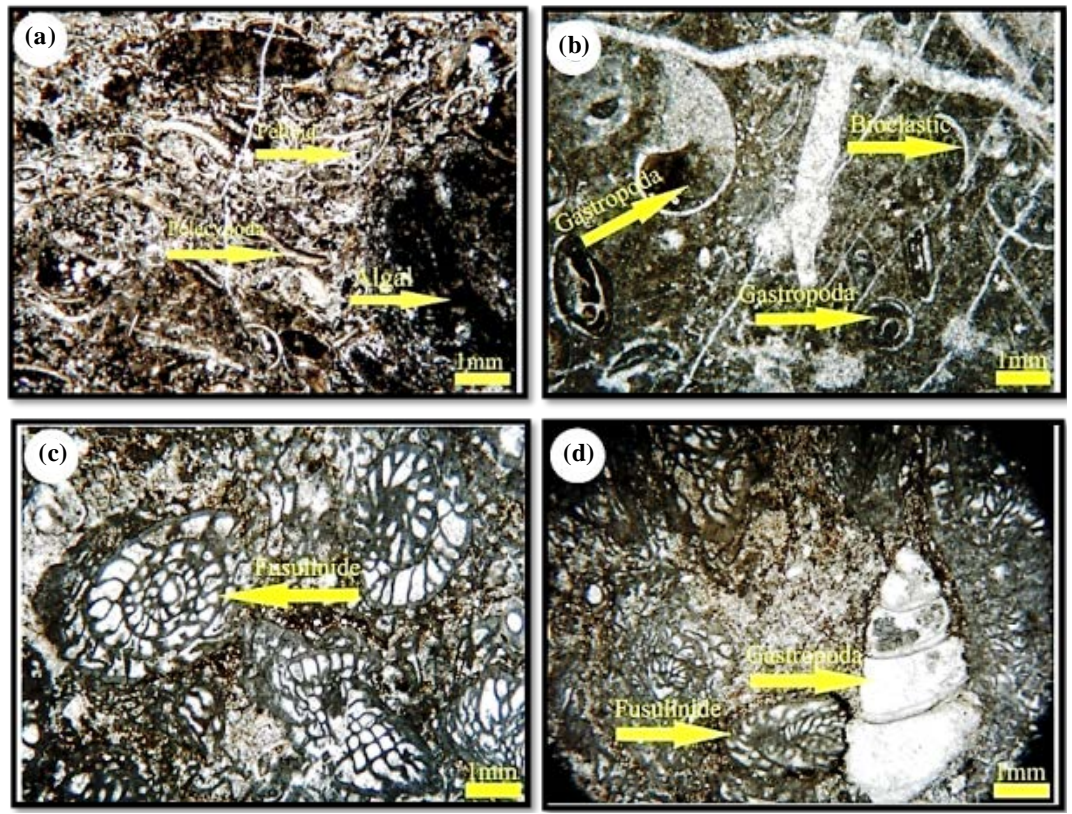

Figure 3. Open and semi-restricted lagoon microfacies: (a) Bioclastic Algal Pelloid Pelecypoda Packstone; (b) Bioclastic Gastropoda Wackestone; (c) Bioclastic Fusulinid Packstone; (d) Fusulinid Packstone.

\subsubsection{B2: Bioclastic Gastropoda Wackestone}

The most important allocherms of this microfacies are Gastropoda (25\%) with 2 to $4 \mathrm{~mm}$ in size and Bioclastic (7\%) with $1 \mathrm{~mm}$ in size. This facies can be found in the form of medium-to-thick bedded limestones with interbedded gray shales (Figure 3(b)).

\subsubsection{B3: Gastropoda Fusulinid Packstone}

The most important allocherms of this microfacies are Fusulinid (40\%) with 3 to 4, Gastropoda (20\%) with 4 $\mathrm{mm}$ in size and Bioclastic (7\%) with $1 \mathrm{~mm}$ in size. This facies can be found in the form of medium-to-thick bedded limestones with interbedded gray shales (Figure 3(c)).

\subsubsection{B4: Fusulinid Packstone}

The major allochem of this facies is Fusulinid (60\%) with $4 \mathrm{~mm}$ in size. This facies can be found in the form of medium-to-thick bedded limestones with interbedded gray shales (Figure 3(d)).

\subsubsection{Interpretation}

Common characteristics among all microfacies of this group include the presence of lime mud between grains and bioclasts resulted from lagoon species, capable of surviving in restricted and semi-restricted conditions [11]-[13]. One of the common characteristics among these facies is the presence of lime mud, non-skeletal pelloid grains and a variety of lagoon bioclasts including algae and gastropoda which can survive in restricted and 
semi-restricted environments [8] [10] [14]-[17]. Bioclastic peloid packstones suggest higher energy conditions in a shallow subtidal setting [18] [19]. The wackestone and packstone textures indicate deposition in the proximal part of a subtidal lagoon [18] [19]. Lagoon and basins separated from sea by bar usually enjoy restricted saline water flow. The amount of salt and oxygen is highly changeable. This area is mainly covered by carbonate deposits in which the most abundant components are pelloids [8] [9] [20] [21]. The abundance of pelloids accounts for sedimentation in a low-energy lagoon environment [8] [11] [20] [22] [23]. The microfacies of this group mostly differ in their fabric type and grain size. Algaes and large foraminifera (fusulinid) are mainly observed in the facies of euphotic zone, consisting of shallow, nutrient-rich water [20] [24]-[28]. Good condition of gastropods and bivalves in these sediments accounts for low movement and erosion and this is one of the characteristics of a restricted low-energy, oxygenated lagoonal environment [21] [29] [30].

\subsection{Shoals and Bar Sub-Environment (Facies C) Consists of the Following Microfacies}

\subsubsection{C1: Ooid Grainstone}

This facies contains $40 \%$ Ooids with 0.5 to $1 \mathrm{~mm}$ in diameter. The core of ooids is composed of Quartz, Echinoderm and Foraminifera. This facies is found as thick-bedded sandstones with brown diagonal lamination (Figure 4(a)).

\subsubsection{C2: Bioclastic Oncoidal Echinid Grainstone}

This facies is mostly composed of 30\% Encoid with $2 \mathrm{~mm}$ in size and 10\% Echinoid with 1 to $1.5 \mathrm{~mm}$ in size. This facies is mainly found as thin-to-thick bedded limestones with interbedded gray shales (Figure 4(b)).

\subsubsection{Interpretation}

Provided that the formation environment of these facies is a shoal or bar environment, various factors including lack of lime mud and a matrix completely made up of cement as well as the grain size account for high rate of energy within the formation period of these facies [8] [31]-[33]. The abundance of ooids points to the sedimentation of high-energy and shallow environments such as shoal and bar environments [8] [31]. Ooid and bioclastic bars and shoal facies are formed in platform margin sub-environment. The skeletal components such as those of echinoderm are mostly found in a high slope, relating to shoal and bar environments [31] [33].

\subsection{Open Marine Sub-Environment (Facies D) Consists of the Following Microfacies}

\subsubsection{D1: Echinid Spiculitic Wackestone}

This facies contain 10\% Echinid with $1 \mathrm{~mm}$ in size, 2\% Ostracode with $1 \mathrm{~mm}$ in size and 15\% Spiculitic with 1 $\mathrm{mm}$ in size. This facies is mainly seen as medium-to-thick bedded limestones with interbedded gray shales (Figure 5(a)).

\subsubsection{D2: Spiculitic Radiolaria Mudstone}

This facies is covered by $3 \%$ Radiolarian in $0.1 \mathrm{~mm}, 1 \%$ Ostracode in $0.5 \mathrm{~mm}$ and 2\% Spiculitic in $0.7 \mathrm{~mm}$. This facies is mainly seen as medium-to-thick bedded limestones with interbedded gray shales (Figure 5(b)).

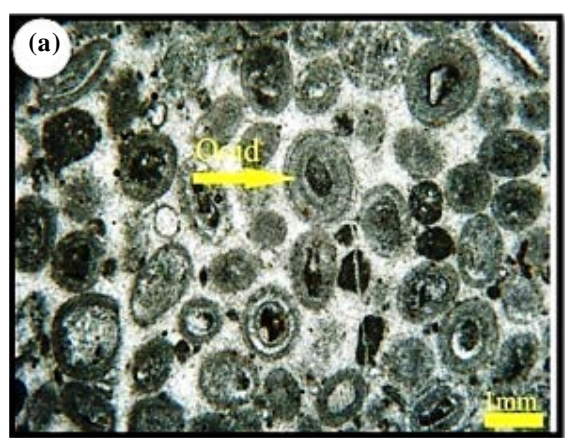

Figure 4. Facies of shoals environment: (a) Echinid Grainstone.

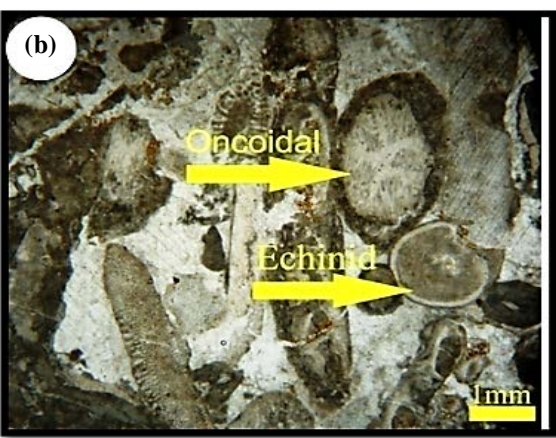

(a) Ooid Grainstone; (b) Bioclastic Oncoidal 

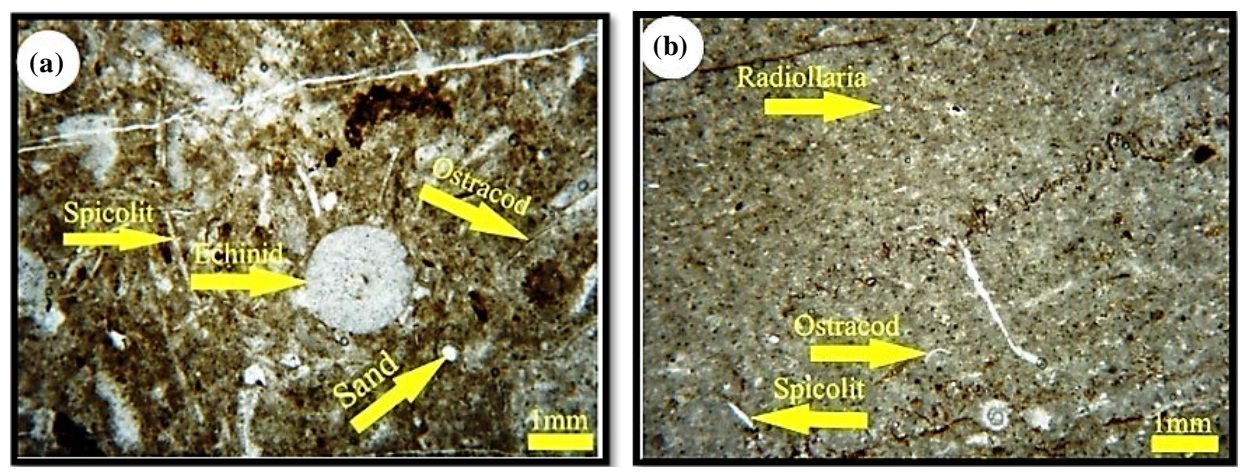

Figure 5. Open marine microfacies: (a) Echinid Spiculitic Wackestone; (b) Spiculitic Radiolarian Mudstone.

\subsubsection{Interpretation}

Fine-sized grains and lack of cement in microfacies 3.4.1 to 3.4.2 account for their deposition in an environment with low-to-mid energy. The presence of spiculitic and radiolaria in a wackestone texture is the sign of the formation of theses microfacies in a deeply open marine environment [11] [34] [35].

\subsection{Frequency Column of Microscopic Facies}

Microscopic facies are divided into two groups of orthochem including ground and cement, and allochem including skeletal and non-skeletal elements. The frequency percentage of orthochem is computed by polarizan microscope and depicted separately for each allochem [10] [11] (Figure 6). The fluctuation curve of sea level is also depicted based on vertical changes in the characteristics of microscopic facies [10] [11] (Figure 7).

\subsection{Sedimentary Environment of Gachal Formation in Rahdar Section}

This model presents the formation system of carbonate facies in the mentioned section under four depositional sub-environments including beach, lagoon, shoal, bar and open marine. These facies are formed in a low-angle homoclinal carbonate ramp and located in the passive margin of southern paleotetis ocean [6] [10] [11] [23] [33]-[36].

Given the described belts, carbonate ramp sedimentary model is suggested for Gachal Formation. Figure 8 shows sedimentary environment model of Gachal Formation in study area.

\subsection{Sequence Stratigraphy in Rahdar Section}

One depositional sequence separated from each other by type 1 sequence boundaries (SB1) is identified in this section. During the formation of type 1 sequence boundary, rate of sea level fall exceeds the tectonic deposits and thus, this depositional environment is completely moved out of water.

According to the studies and comparisons made between various sections of Rahdar section in the Kalmard block, one depositional sequence with various characteristics including the followings are recognized.

\subsubsection{First Depositional Sequence}

As a destructive-carbonate sequence, this depositional sequence, with 55 m thickness, is the first studied sequence restricted by type 1 sequence boundary at its base and top. In this sequence, the LST sediments are formed by expanding beach facies through type 1 unconformity. LST sediments enjoy Quartz-arenite petrofacies which, on their own merits, include aggradational and progradational parasequences. This set of facies appears as the sea level falls. In deserts, it can be found as thick-to-thin bedded sandstone with horizontal lamination. One of the consequences of the LST process in the destructive-carbonate systems is the development of destructive sediments. Once the sea level goes up to the edge of continental shelf, destructive substances increasingly enter the environment [37].

TST sediments, with Bioclastic Algal Pelloid Pelecypoda Wackestone, Lagoonal Bioclastic Fusulinid Packstone and bar Bioclastic Encoid Grainstone, are progradationally deposited on LST sediments. TST sediments 


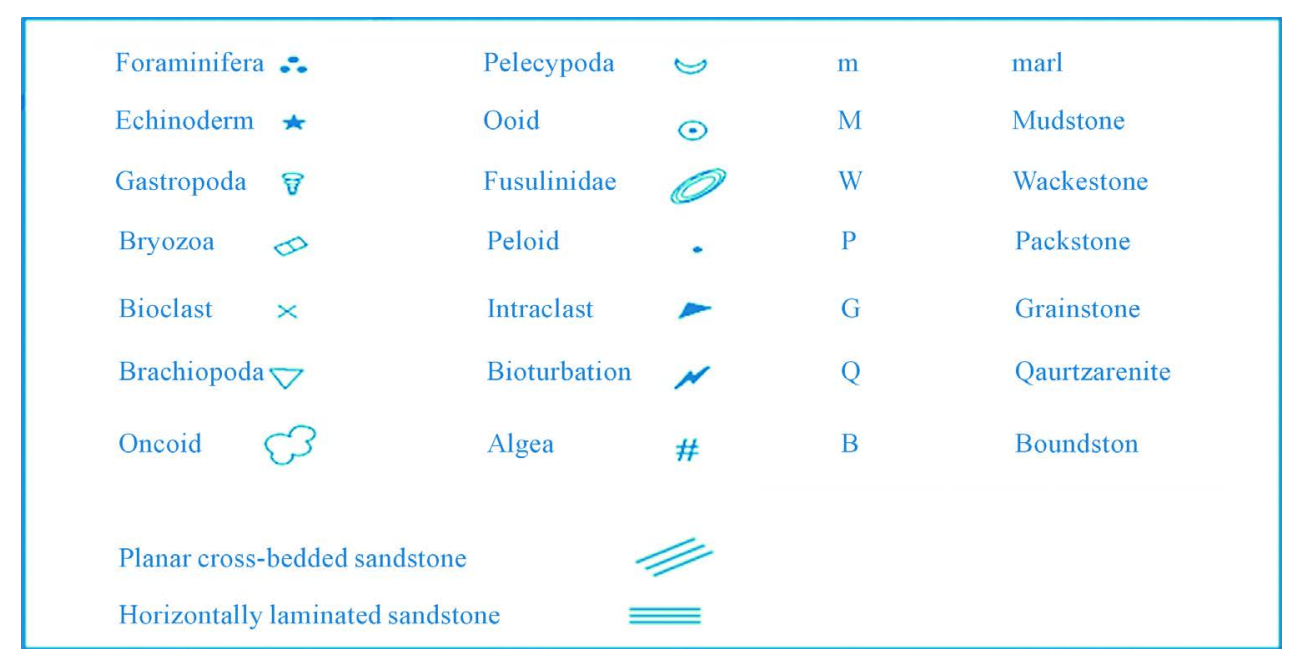

Figure 6. The guide for Figure 7.

contain a Parasequences and are seen as medium-to-thick bedded limestones interbedded with gray shales. After that, the highest level of MFS identified by mudstone facies consisting of open marine Radiolaria and Spiculitic is seen. In this situation, the area is located between maximum rate of relative sea level rise and maximum sea level. Therefore, TST sediments can be easily found in this situation in the desert.

Due to the fluctuations in the sea level, HST sediments, on the other hand, are aggradationally formed as a result of open marine, lagoon and bar facies stacking. HST sediment contains Early HST and Late HST parasequences.

Early HST parasequences result from accumulation of lagoon cycles with bar (Bioclastic Gastropoda Wackestone and Fusulinid Packstone) and open marine (Bioclastic Encoid Ochinid Grainstone) facies, retrogradationally reach Late HST sediments. Early HST parasequences can be found as medium-to-thick bedded limestones with interbedded gray shales.

Late HST parasequences, formed due to bar facies stacking (Ooid Grainstone) can be seen in the form of diagonally laminated Mudstone (Figure 9 and Figure 10).

\subsubsection{Interpreting Depositional Sequences of Rahdar Section}

Facies evolution and sequence stratigraphy of the carboniferous deposits in the studied section are analyzed and compared with sub-sequences such as Kaskaskia introduced at the global scale (asterisk position in Figure 11 and Figure 12) [38]. The lower boundary of the first depositional sequence of Gachal Formation in Rahdar section is of type 1 (SB1).

The first depositional sequence in Rahdar section consists of sandstone and limestone parasequences interbedded with shales. The relative sea level fall results in the formation of beach deposits at the initial part of this sequence. MFS in this sequence is identified by open marine Radiolarian Mudstone facies. It is noteworthy that Rahdar section ends up type 1 sequence boundary and consequently moves out of water. Due to its shallow depth, sedimentary basin meaningfully reacts towards sea level fluctuations in the destructive-carbonate platform of Kalmard Block.

\section{Conclusions}

1) This facies can be found in four facies belt zones of Beach (A), Lagoon (B), Shoal (C), Open marine (D).

2) Given their vertical changes columns, these facies have been deposited on a Homoclinal carbonate ramp platform related Carboifer periods.

3) Based on field and laboratory observation in Gachal Formation in study area, 8 carbonate facies and 2 clastic-carbonate facies have been recognized.

4) Carbonated facies include Mudstone, Bioclastic Algal Pelloid Pelecypoda Packstone, Bioclastic Gastropoda Wackestone, Gastropoda Fusulinid Packstone, Fusulinid Packstone, Ooid Grainstone, Bioclastic Oncoidal Echinid Grainstone, Echinid Spiculitic Wackestone, and Spiculitic Radiolaria Mudstone. 
M. J. Javdan et al.

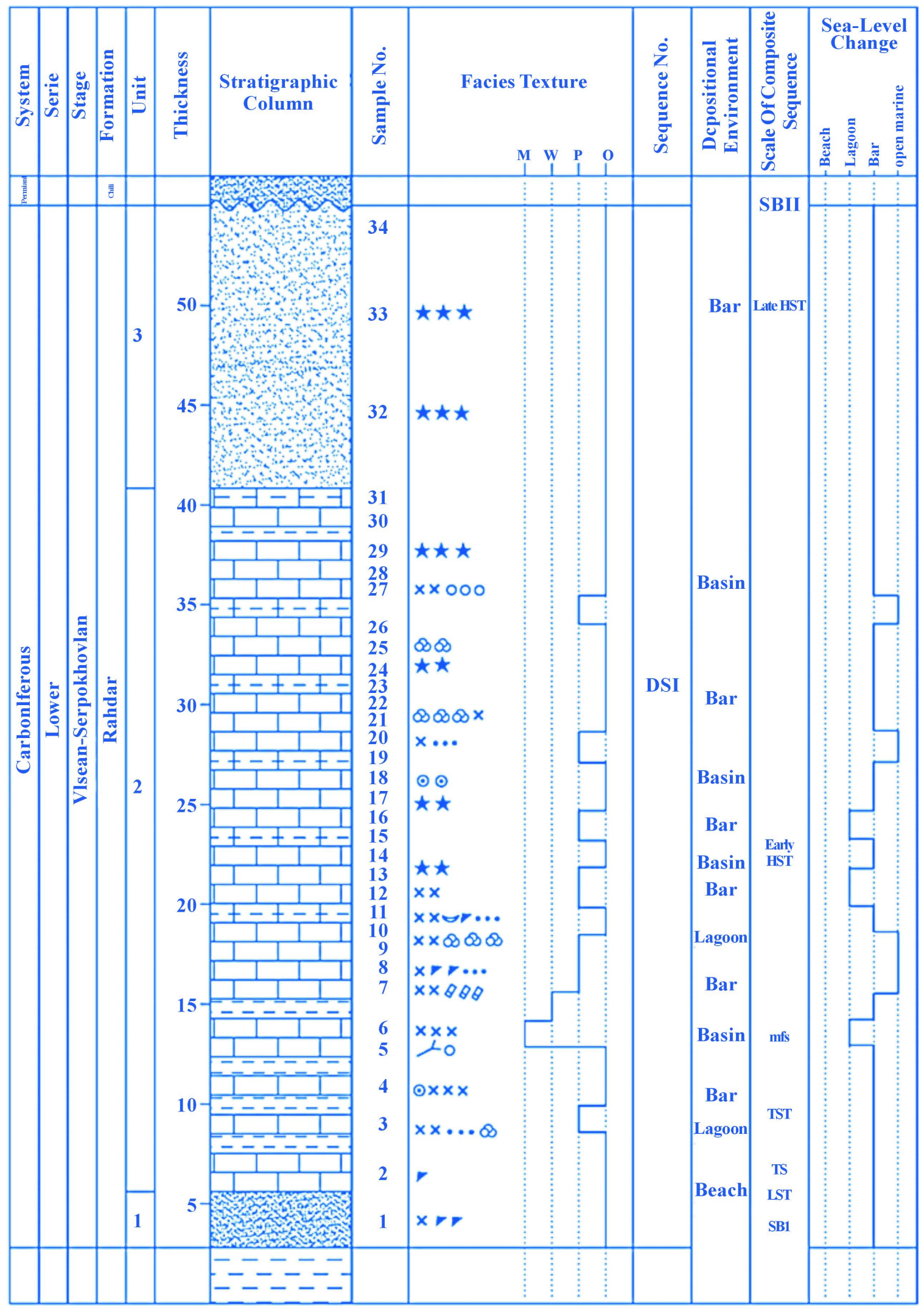

Figure 7. Microscopic facies column of Gachal formation in Rahdar section. 


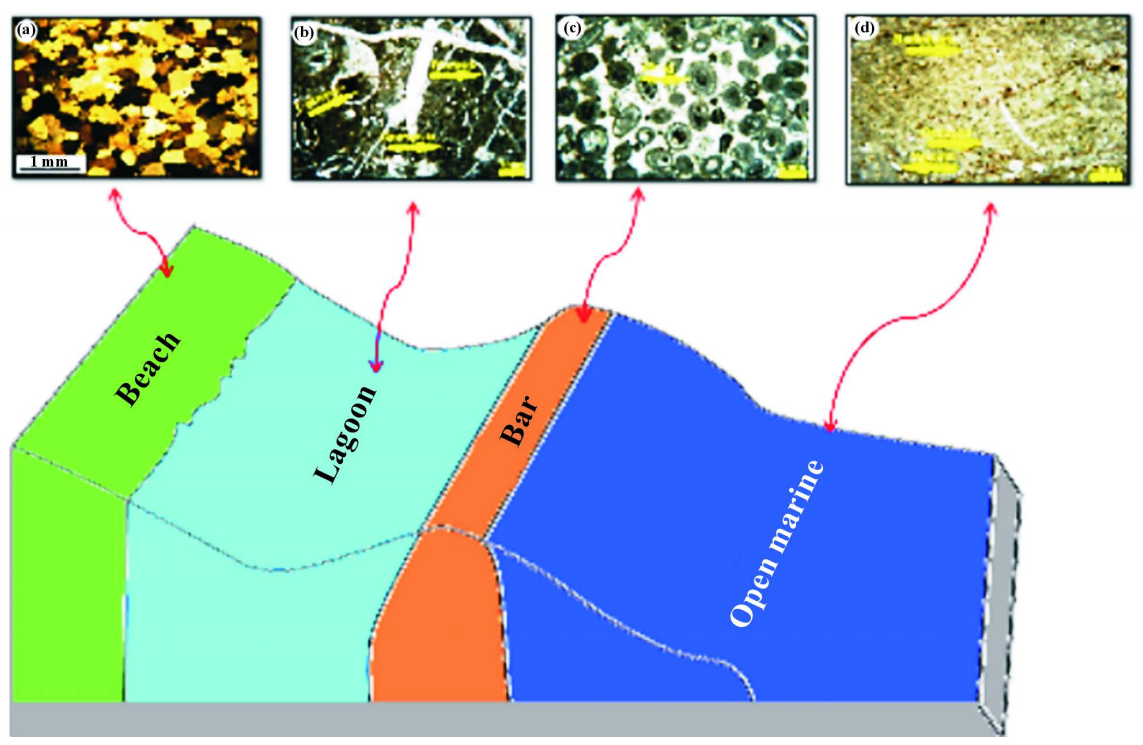

Figure 8. Depositional environment model: the sediments of this section are formed in a homoclinal ramp.

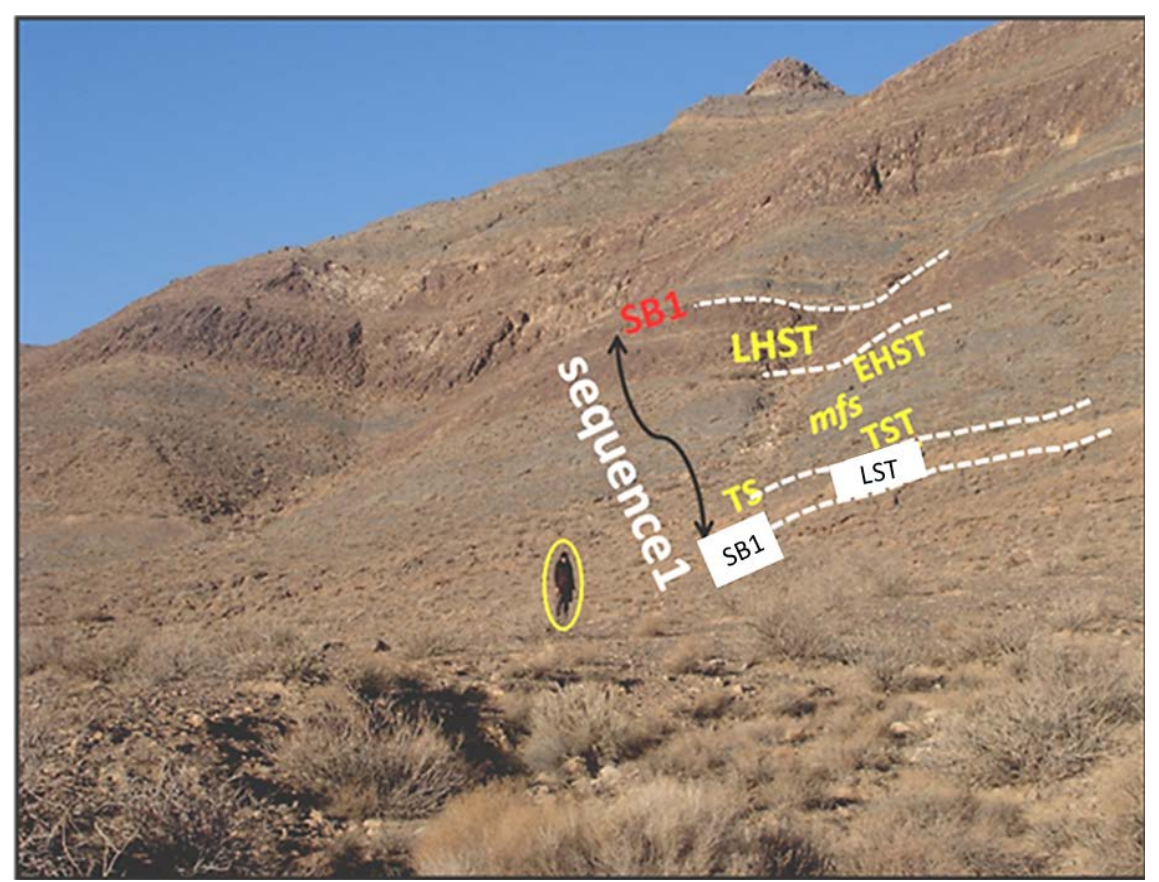

Figure 9. First depositional sequence: LST contains Beach sandstones as well as quartsarenite facies; TST consists of interbedded lagoonal shale limestones with Bioclastic Oncoid Echinid Grainstone; MFS comprises of interbedded Open marine shale limestones with Radiolaria Mudstone; EHST is composed of interbedded lagoonal (Bioclastic Gastropoda Wackestone and Fusulinid Packstone), Bar (Bioclastic Oncoid Echinid Grainstone), open marine (Radiolaria and Spiculitic Mudstone) shale limestones; LHST consists of bar sandstone with Ooid Grainstone facies.

5) Clastic facies (Lithofacies) include horizontally laminated sandstone (Sh), and planar cross-bedded sandstone (sp).

6) These sequences are equivalent to the upper part of Kaskaskia IV great cycle and are compatible with and similar to the proposed sequences for other parts of the world (Figure 11 and Figure 12). 


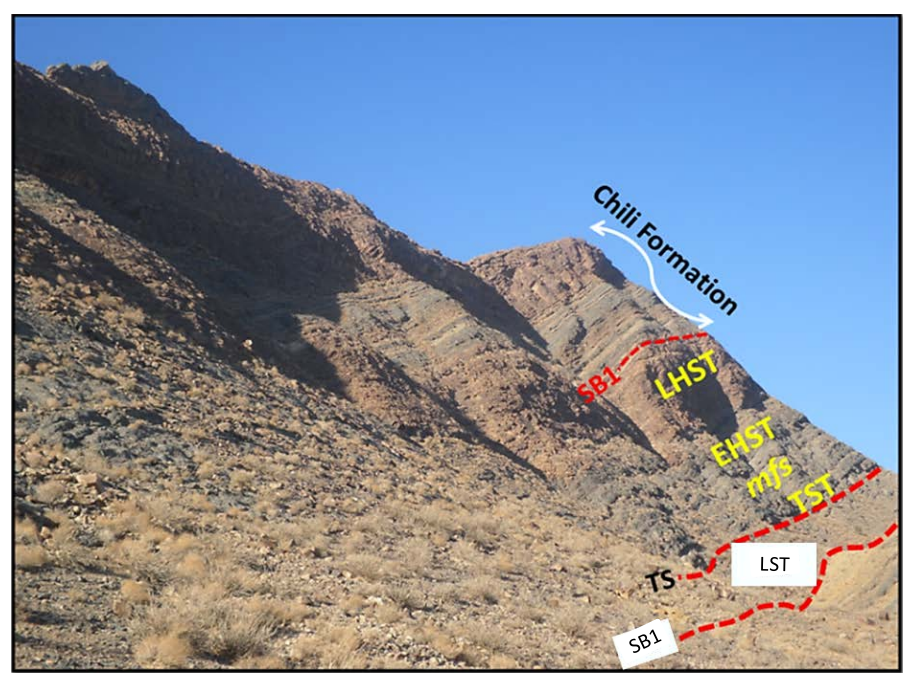

Figure 10. An outline of the first depositional sequence: LST contains beach sandstones as well as quarts-arenite facies; TST consists of interbedded Lagoonal shale limestones with Bioclastic Oncoid Echinid Grainstone; MFS comprises of interbedded Open marine shale limestones with Radiolaria Mudstone; EHST is composed of interbedded Lagoonal (Bioclastic Gastropoda Wackestone and Fusulinid Packstone), Bar (Bioclastic Oncoid Echinid Grainstone), Open marine (Radiolaria and Spiculitic Mudstone) shale limestones; LHST consists of Bar sandstone with Ooid Grainstone Facies.

\begin{tabular}{|c|c|}
\hline Quatennary & $-1-1-1-1$ \\
\hline Tertiary & TEJAS $\leq$ \\
\hline & $\therefore-=------1=$ \\
\hline Cretaceous & ZUNI $\quad-\square=---$ \\
\hline Jurassic & $\therefore$ \\
\hline Triassic & $\sum$ \\
\hline Permian & $z--\overline{-}-\overline{-}-\overline{ }$ \\
\hline Pennsylvanian & ABSAROKA \\
\hline Mississippian & KASKASKIA $\quad+$ Gachal formation \\
\hline Devonian & 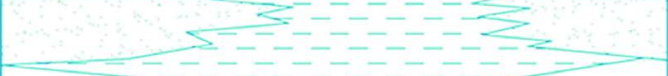 \\
\hline Silurian & TIPPECANOE \\
\hline Ordovician & ए $-2-2$ \\
\hline Cambrian & 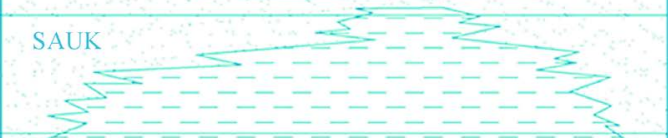 \\
\hline Precambrian & 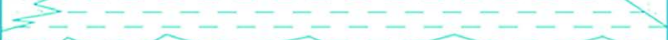 \\
\hline 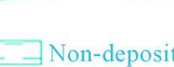 & Appalachian Basin $\succ$ \\
\hline
\end{tabular}

Figure 11. The position of the studied formation as well as its parasequences at the global scale is represented by *. 


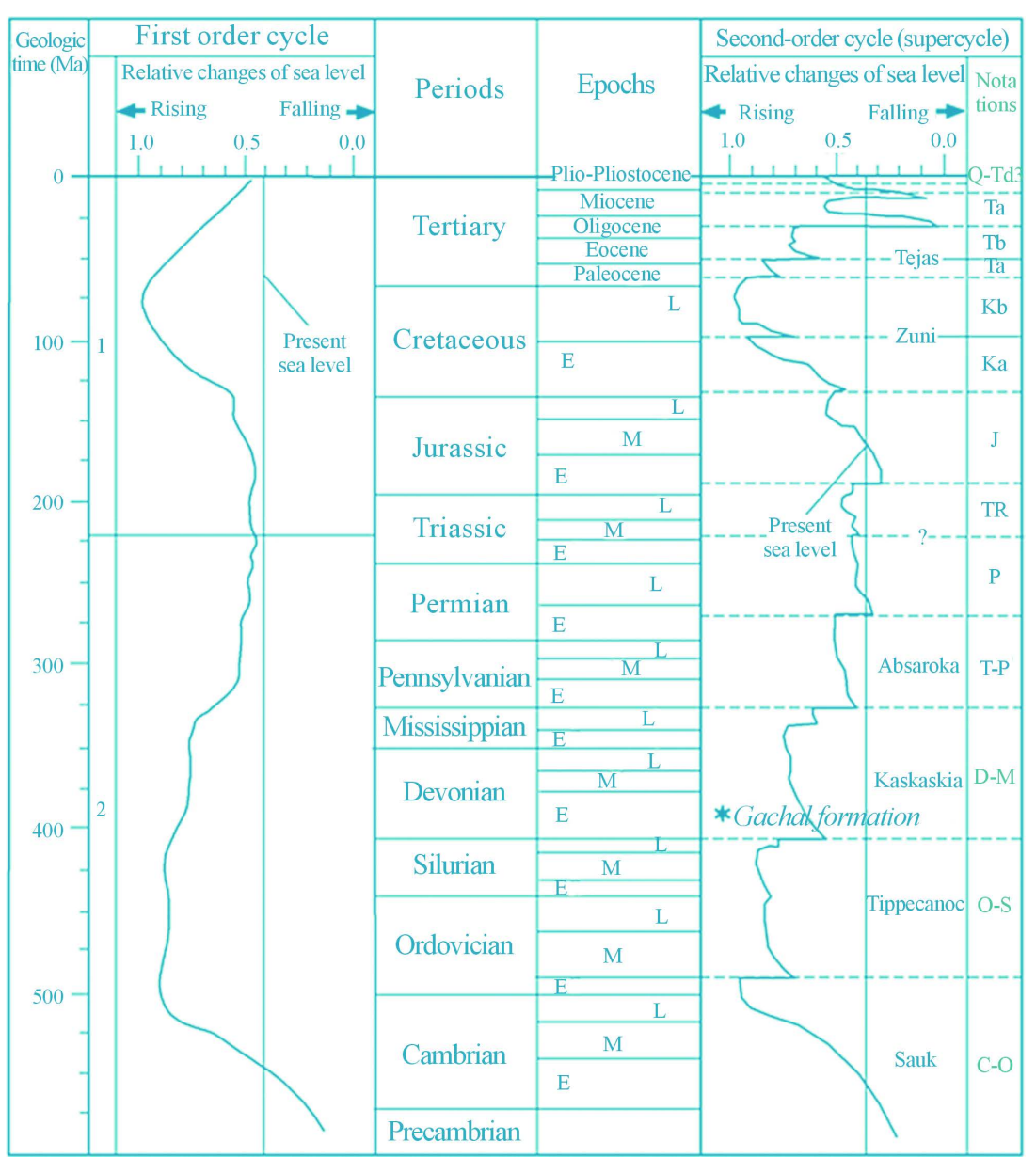

Figure 12. Global sea level curve. Type 1 and type 2 cycles, according to which early carboniferous are located within Late Kaskaskia. The period of the studied sequence is shown by *.

7) In Rahdar section, the first identified depositional destructive-carbonate sequence begins with type 1 sequence boundary and ends with type 1 sequence boundary.

8) In this section, MFS contains radiolarian and spiculitic facies.

\section{References}

[1] Aghanabati, A. (1983) Major Structural Zone Sedimentary Iran. Geological and Country Mineral Exploration Organization, Iran, 606.

[2] Aghanabati, A. (1977) Etudgeologique de la region de Kalmard (W. Tabas). Geological Survey of Iran, 51-63.

[3] Tucker, M.E. (2001) Sedimentary Petrology. 3rd Edition, Blackwell, Oxford, 260 p.

[4] Miall, A.D. (2006) The Geology of Fluvial Deposists: Sedimentary Facies, Analysis and Petroleum Geology. SpringVerlag, New York, 582. http://dx.doi.org/10.1007/978-3-662-03237-4

[5] Therrien, F. (2006) Depositional Environments and Alluvial System Changes in the Dinosaur-Bearing Sânpetru Formation (Late Cretaceous, Romania): Post-Orogenic Sedimentation in an Active Extensional Basin. Sedimentary Geology, 192, 183-205. http://dx.doi.org/10.1016/j.sedgeo.2006.04.002

[6] Strand, K. (2005) Sequence Stratigraphy of the Silisiclastic East Puolanka Group, the Palaeoproterozoic Kainuu Belt, Finland. Sedimentary Geology, 176, 149-166. http://dx.doi.org/10.1016/j.sedgeo.2004.12.014

[7] Pettijohn, F.J., Siever, R. and Potter, P.E. (1987) Sand and Sandstone. 2nd Edition, Springer-Verlag, Berlin, 553 p. http://dx.doi.org/10.1007/978-1-4612-1066-5

[8] Wilson, J.L. (1975) Carbonate Facies in Geologic History. Springer, New York, 471 p. 
http://dx.doi.org/10.1007/978-1-4612-6383-8

[9] Khalifa, M.A., Soliman, H.E. and Wanas, H.A. (2006) The Cambrian Araba Formation in Northeastern Egypt: Facies and Depositional Environments. Journal of Asian Sciences, 27, 873-884. http://dx.doi.org/10.1016/j.jseaes.2005.09.003

[10] Shahraki, J., Javdan, M.J., Hashemi, S.M.P., Jami, M., Nastooh, M. and Kalvandi, S.M. (2015) Facies Analysis, Depositional Environment of the Lower Permian Deposits of Chili Formation in Kalmard Block, Eastern Central Iran (Darin Section). Open Journal of Geology, 5, 539-551. http://dx.doi.org/10.4236/ojg.2015.58049

[11] Shahraki, J., Mousavi-Harami, R., Mahboubi, A. and Jahani, D. (2014) Facies Analysis, Depositional Environment and Cyclostratigraphy of the Lower Permian Deposits Chili Formation in the Kalmard Block, East Central Iran (Godar-e-Gachal Section). Indian Journal of Science and Technology, 7, 1588-1602. http://www.indjst.org

[12] Basso, D., Nalin, R. and Nelson, C.S. (2009) Shallow-Water Sporolithon Rhodoliths from North Island (New Zealand). Palaios, 24, 92-103. http://dx.doi.org/10.2110/palo.2008.p08-048r

[13] Nebelsick, J.H., Rasser, D. and Lwmpp, J. (2012) Tracking Paleoenvironmental Changes in Coralline Algal-Dominated Carbonates of the Lower Oligocene Calcareniti di Castelgomberto Formation (MontiBerici, Italy). Facies, 59, 133-148. http://dx.doi.org/10.1007/s10347-012-0349-6

[14] Sahraeyan, M., Bahrami, M. and Arzaghi, S. (2013) Facies Analysis and Depositional Environments of the OligoceneMiocene Asmari Formation, Zagros Basin, Iran. Geoscience Frontiers, 5, 103-112. http://dx.doi.org/10.1016/j.gsf.2013.03.005

[15] Mahboubi, A., Moussavi-Harami, R. and Lasemi, Y. (2001) Sequence Stratigraphy and Sea Level History of the Upper Paleocene Strata in the Kopet-Dagh Basin, Northeastern Iran. American Association of Petroleum Geologists Bulletin, 85, 839-859.

[16] Shinn, A. (1983) Tidal Flat Environment. In: Schlle, P.A., Debout, D.G. and Moore, C.H., Eds., Carbonate Depositional Environment: AAPG Memoir, American Association of Petroleum Geologists, Tulsa, 173-210.

[17] Briand, C., Izart, A., Vaslet, D., Vachard, D., Makhlina, M., Goreva, N., Isakova, T., Kossovaya, O. and Jaroshenko, A. (1998) Stratigraphy and Sequence Stratigraphy of Moscovian, Kasimovian and Gzhelian in the Moscow Basin. Bulletin de la Societe Geologique de France, 169, 35-52.

[18] Lasemi, Y. (1998) Sedimentary Environment of Iran Ordovician Stones (Same Sequences of Sedimetray, Environment of Rift Formation) and the Formation of Divergent Margins of Paleo-Tethyhs. Seventeen Meeting of Earth Sciences, Geological and Country Mineral Exploration Organization, 158-160.

[19] Jamalian, M. (2011) Facies Characteristic and Paleoenvironmental Reconstruction of the Fahliyan Formation, Lower Cretaceous, in the Kuh-e Siah Area, Zagros Basin, Southern Iran. Facies, 57, 101-122.

[20] Flügel, E. (2010) Microfacies of Carbonate Rocks, Analysis, Interpretation and Application. Springer-Verlag, Berlin, $996 \mathrm{p}$.

[21] Sepkoski Jr., J.J., Bambach, R.K. and Dorser, M.L. (1991) Secular Changes in Phanerozoic Event Bedding and the Biological Overprint. In: Einsele, G., Rieken, W. and Scilacher, A., Eds., Cycles and Event in Stratigraphy, SpringerVerlag, Berlin, 298-312.

[22] Brandano, M., Frezza, V., Tomassetti, L. and Pedley, M. (2010) Facies Analysis and Paleoenvironmental Interpretation of the Late Oligocene Attard Member (Lower Coralline Limstone Formation), Malta. Sedimentalogy, 56, 1138-1158. http://dx.doi.org/10.1111/j.1365-3091.2008.01023.x

[23] Vaziri-Moghadam, H., Kimiagari, M. and Taheri, A. (2006) Depositional Environment and Sequence Stratigraphy of the Oligo-Miocene Asmari Formation in SW Iran. Facies, 52, 41-51. http://dx.doi.org/10.1007/s10347-005-0018-0

[24] Ali, Y.A. and West, I. (1983) Relationships of Modern Gypsum Nodules in Sabkhas of Loess to Compositions of Brines and Sediments in North Egypt. Journal of Sedimentary Petrology, 52, 1151-1168.

[25] Butler, G.P., Harris, P.M. and Kendall, C.G.S.C. (1982) Recent Evaporites from the Abu Dhabi Coastal Flats. In: Handford, C.R., Loucks, R.G. and Davies, G.R., Eds., Deposition and Diagenetic Spectra of Evaporites-A Core Workshop, SEPM Core Workshop No. 3, 33-64. http://dx.doi.org/10.2110/cor.82.01.0033

[26] Kendall, C.G. and Warren, J.K. (1989) Peritidal Evaporates and Their Sedimentary Assemblage. In: Schreiber, B.C., Ed., Evaporates and Hydrocarbons, Columbia University Press, New York, 66-138.

[27] Fridman, G. (1995) The Arid Peritidal Complex of Abu Dhabi: A Historical Perspective. Carbonates and Evaporites, 10, 2-7. http://dx.doi.org/10.1007/BF03175237

[28] Bromley, R.G. (1990) Trace Fossils: Biology and Taphonomy. Unwin Hyman Ltd, London, 280 p.

[29] Wetzel, A. (1991) Ecologic Interpretation of Deep Sea Trace Fossil Communities. Palaeogeography, Palaeoclimatology, Palaeoecology, 85, 47-69. http://dx.doi.org/10.1016/0031-0182(91)90025-M

[30] Ghosh, A.K. and Sarkar, S. (2013) Facies Analysis and Paleoenvironment Interpretation of Piacenzian Carbonate Deposits from the Guitar Formation of Car Nicobar Island, India. Geosience Frontiers, 4, 755-764. 
http://dx.doi.org/10.1016/j.gsf.2013.01.010

[31] Amirshahkarami, M., Vaziri-Moghaddam, H. and Taheri, A. (2007) Sedimentary Facies and Sequence the Asmari Formation at Chaman-Bolbol, Zagros Basin, Iran. Journal of Asian Earth Sciences, 29, 947-959. http://dx.doi.org/10.1016/j.jseaes.2006.06.008

[32] Lasemi, Y. (1995) Platform Carbonates of the Upper Jurassic Mozduran Formation in the Kopet Dagh Basin, NE Iran-Facies, Palaeoenvironments and Sequences. Sedimentary Geology, 99, 151-164. http://dx.doi.org/10.1016/0037-0738(95)00041-6

[33] Burchette, T.P. (1993) Mashrif Formation (Cenomanian-Turonian), Southern Persian Gulf: Carbonate Platform Growth along a Cratonic Basin Margin. In: Simo, J.A.T., Scott, R.W. and Masse, J.-P., Eds., Cretaceous Carbonate Platforms, AAPG Memoir No. 56, 185-200.

[34] Read, J.F. (1985) Carbonate Platform Facies Models. American Association of Petroleum Geologists Bulletin, 69, 1-21.

[35] Bachmann, M. and Hirisch, F. (2006) Lower Cretaceous Carbonate Platform of the Eastern Levant (Galilee and the Golan Heights): Stratigraphy and Second-Order Sea-Level Change. Cretaceous Research, 27, 487-512. http://dx.doi.org/10.1016/j.cretres.2005.09.003

[36] Boudagher-Fadel, M.K. and Lokier, S.W. (2005) Significant Miocene Larger Foraminifera from South Central Java. Revue de Paléobiologie, 24, 291-309.

[37] Alonso-Zarza, A.M. and Tanner, L.H. (2010) Carbonates in Continental Setting: Facies, Environments and Processes. Developments in Sedimentology, 61, 225-267.

[38] Sloss, L.L. (1963) Sequence in Cratonic Interior of North America. Geological Society of America Bulletin, 74, 93-114. http://dx.doi.org/10.1130/0016-7606(1963)74[93:SITCIO]2.0.CO;2 